\title{
THE USES OF ISOLATED PROTOPLASTS IN PLANT GENETICS
}

\author{
D. J. COVE \\ Department of Genetics, University of Leeds, Leeds LS2 9JT
}

Received 16.vii.79

\section{Summary}

\begin{abstract}
Protoplasts may be isolated from a wide range of fungal and green plant species. In many of these, protoplasts can be induced to regenerate, and to give either plants directly, or cell cultures, which may in turn subsequently give rise to plants. Fusion of protoplasts can be induced by a variety of agents, and it may be possible to select hybrid cell lines or plants following treatment of mixtures of protoplasts. Hybrid selection procedures include direct visual selection using fusion partners which are morphologically distinct, and various procedures which involve the use of complementing mutant strains.

Somatic hybridisation following protoplast fusion has led to the selection of novel hybrids, not obtainable by sexual hybridisation, and has made possible the genetic analysis of sexually sterile strains. It also provides a unique method of studying cytoplasmic inheritance in higher plants, and allows the construction of strains having new combinations of nuclear and cytoplasmic genomes.

Isolated protoplasts are likely to be excellent material for mutagenic treatment and because they take up a wide range of material, they are also valuable in a variety of genetic techniques, aimed at the transfer of specific genetic information into plant species. Protoplasts have been utilised in the experiments leading to transformation in Saccharomyces cerevisiae.
\end{abstract}

\section{INTRODUCTION}

A SUFFICIENT number of reviews of work involving the use of isolated plant protoplasts has appeared recently (see for example: Bhojwani et al., 1977; Cocking, 1977, 1978; Eriksson, 1977; Gamborg, 1977a, b; Gamborg and Holl, 1977; Melchers, 1977a, b, c; Constabel, 1978; Eriksson et al., 1978; Smith, 1978; Vasil et al., 1978; Gamborg et al., 1979) for me to feel that I should justify the production of yet another. It is true that the field is developing rapidly, making reviews quickly out of date, and it is also true that few reviews cover both work involving fungi and work using green plants, as this review does. However, the principal purpose of this review is to introduce the field to those unfamiliar with it, to allow them to assess for themselves the achievements and potentialities of work using isolated protoplasts for genetic analysis. In short, this review is not intended for those already working with isolated protoplasts, although I must thank many of them for making both published and unpublished material available to me so freely.

\section{Definitions}

The protoplast is the part of a cell bounded by the outer membrane or plasmalemma. The removal of the cell wall from a bacterial or plant cell, under conditions which osmotically stabilise the protoplast, leads to the release of isolated spherical protoplasts, and it is these which are the material used 
for the studies described here. In studies where isolated protoplasts are used to determine the effects of the removal of the cell wall, it is obviously necessary to be sure that no cell wall material remains on the isolated protoplast. Brenner et al. (1958) suggested criteria for judging whether bacterial protoplasts were free of cell wall material and many of these could also be applied, suitably modified, to plant protoplasts. For the genetic studies reviewed here, however, complete removal of the cell wall is less important and the term "isolated protoplast" is used widely without critical tests for the absence of cell wall material having necessarily been carried out. The term "spheroplast" is also used widely, particularly in bacterial and fungal studies, and although this term is often used to indicate that some cell wall material may remain, its use is probably not consistent enough to be worth while. Finally, it is now common practice to omit adjectives such as " isolated " or " naked" in describing protoplasts, where the context makes them unnecessary, and while it might be judged uncritical, I shall for the sake of brevity adopt this practice in this review.

Some problems of terminology also arise over the correct term for the product of fusion of two protoplasts. Where cytoplasmic fusion but no nuclear fusion occurs, the terms " homo-" and " heterokaryon ", depending on whether the protoplasts were from the same or different strains, are correct. Where nuclear fusion occurs no equivalent terms are available. The term "heterokaryocyte" is used by some workers, but this usually embraces all fusion products between two different strains, whether or not nuclear fusion has occurred.

\section{Protoplast Teghnology}

(i) Protoplast isolation

Protoplasts were first isolated from plant cells in the nineteenth century, and reports of successful protoplast isolation appeared sporadically during the first half of this century (see for example: Klercker, 1892; Küster, 1910; Chambers and Höfler, 1931; Michel, 1937; Hofmeister, 1954). These studies generally employed methods in which the protoplasts were first plasmolysed and then released either spontaneously or by agitation following mechanical disruption of the cell wall, usually by cutting. Such methods yielded only low numbers of protoplasts, the viability of which it is difficult to assess.

The technical breakthrough which led to the isolation of protoplasts in large numbers was the employment of enzymes to degrade the cell wall. Weibull (1953) used this technique to isolate protoplasts of the bacterium, Bacillus megaterium, using the enzyme, lysozyme. The technique was next extended to fungi, where an enzyme which degrades fungal cell walls isolated from the snail, Helix pomata (Giaja, 1922), was generally employed. Using this enzyme, which is usually referred to as "snail enzyme" or helicase, Eddy and Williamson (1957) isolated protoplasts of the yeasts, Saccharomyces carlsbergiensis and $S$. cerevisiae, although protoplasts of the latter species had been isolated earlier by Nečas (1956) using either mechanical pressure or autolysis. Eddy and Williamson (1957) emphasise that protoplasts are released more readily from young cells, presumably because the cell wall is less well developed, and this applies to most green plant material too. The use of snail enzyme was extended to other fungal species including Neurospora 
crassa (Bachmann and Bonner, 1959). Emerson and Emerson (1958) used hemicellulase to isolate $\mathcal{N}$. crassa protoplasts, employing an os mutant strain, sensitive to high osmolarities. Hamilton and Calvet (1964) also obtained $\mathcal{N}$. crassa protoplasts from an osmotically sensitive strain, but developed a technique where enzymatic treatment was unnecessary. Emerson (1963) reported another strain, "slime", of $\mathcal{N}$. crassa, which similarly gave rise spontaneously to protoplasts. Fungal protoplasts can also be isolated using cell wall lytic enzymes isolated from medium in which Streptomyces violaceus has been grown (see Villanueva, 1966).

Enzymes were first employed to isolate protoplasts from green plant material by Cocking (1960), who used a cellulase from the fungus Myrothecium verrucaria to isolate protoplasts from root tips of Lycopersicum esculentum. A number of enzymes which degrade green plant cell walls are now obtainable commercially, and it is often found more effective to employ a mixture of enzymes, including for example a pectinase, a cellulase and a hemicellulase, to achieve optimum isolation.

To survive the removal of the cell wall, it is essential that protoplasts be osmotically buffered, and a variety of solutes have been employed to achieve this, including inorganic salts such as $\mathrm{NaCl}$, or sugars such as sucrose or mannitol. The choice of solute may be critical, both for the optimisation of the isolation procedure and for the continued viability of the isolated protoplast.

The techniques for the isolation of plant protoplasts have now been refined sufficiently to allow routine isolation of protoplasts in extremely large numbers, and it is not uncommon to obtain $10^{8}$ or more protoplasts from $1 \mathrm{~g}$ wet weight of plant tissue (Banks and Evans, 1976; Grimsley et al., 1977a). Protoplast isolation is therefore unlikely any longer to be a critical step in devising techniques which utilise protoplasts.

\section{(ii) Protoplast regeneration}

For almost all genetic applications, it is essential that isolated protoplasts can be induced to regenerate, preferably to give a whole plant. This presents few problems for fungal protoplasts, where direct regeneration to give mycelium was observed even in early work (Nečas, 1956). Gulture of fungal protoplasts on nutritive media, containing a suitable osmotic buffer, generally leads to a rapid regeneration of a cell wall. Regeneration of protoplasts from green plants has proved much more difficult to achieve due in part to the more complex growth conditions required. Binding (1966) demonstrated that protoplasts isolated from moss stems regenerated directly to give protonema. These gave rise to gametophytes which were polyploid, but it is possible that this was due to the polyploid nature of the cells from which the protoplasts were isolated, rather than to the regeneration process itself. Success with higher plant material took longer; Pojnar et al. (1967) reported cell wall regeneration by protoplasts of Lycopersicum esculentum, Eriksson and Jonasson (1969) observed limited nuclear division in cultured protoplasts of Haplopappus gracilis, Nagata and Takebe (1970) succeeded in obtaining cell division with Nicotiana tabacum protoplasts, and finally Nitsch and Ohyama (1971), Nagata and Takebe (1971) and Takebe t al. (1971) all described methods for $\mathcal{N}$. tabacum which achieved protoplast regeneration via callus, to give ultimately whole plants. Since then, methods have been described for 
many other higher plant species, but by no means all attempts at regeneration have so far been successful (see for example Schieder, 1977b). Protoplasts from cereals prove to be particularly obstinate. Potrykus et al. (1976, 1977a, b) describe experiments in which more than 80,000 different combinations of media, plant species and varieties (mostly Triticum aestivum and Hordeum vulgare) and protoplast sources were tried without success, although the same group (Potrykus et al., 1977b) eventually achieved success with Zea mays, at least in achieving protoplast regeneration to give callus cultures. It is likely that the problems which arise in achieving protoplast regeneration have two sources. Firstly, protoplasts may be damaged in the isolation procedure so as to reduce their viability. This risk is reduced by minimising the length of time that cells are treated with degradative enzymes to achieve protoplast release, and the choice of starting material is also likely to be crucial here. The second problem is the difficulty of devising culture conditions for some species, and this problem extends to callus cultures as well. This second problem is likely to prove the more intractable of the two, but it is nevertheless probable that progress will be made fairly rapidly.

\section{(iii) Protoplast fusion}

One of the most important potential uses of isolated protoplasts in plant genetics is likely to be the generation of somatic hybrids, the possible uses of which are discussed in section 4 of this review. The fusion of protoplasts is a crucial step in the generation of a somatic hybrid. In early studies of protoplasts, spontaneous fusion between protoplasts isolated from a uniform tissue was sometimes observed, and a systematic study of fusion, including the use of micromanipulation to facilitate fusion events, was made by Michel (1937) who achieved not only fusion between protoplasts isolated from the same species, but also from different species including the fusion of protoplasts from the alga Chara fragilis with those from Brassica oleracea. Fusion was also achieved mechanically using a micropipette by Hofmeister (1954). As with all early studies, it is difficult to assess in these cases the viability of the protoplasts used, or of their fusion products. Binding (1966) observed spontaneous fusion of moss protoplasts, and attempted to increase the fusion frequency by the use of treatments chosen to damage the plasmalemma, such as the addition of finely splintered glass. However, the treatments employed damaged the protoplasts sufficiently to make regeneration extremely infrequent, and although agglutination occurred between protoplasts isolated from different species, no permanent fusion occurred to give a stable product. Lopez-Belmonte et al. (1966) also observed fusion between protoplasts isolated from the fungus, Fusarium culmorum, but no regeneration of a fused product is reported. As the potential uses of protoplast fusion became appreciated, research aimed at identifying treatments which enhanced protoplast fusion increased (Schenk and Hildebrandt, 1970). Power et al. (1970) reported that treatment of protoplasts with $250 \mathrm{mM} \mathrm{NaNO} \mathrm{m}_{3}$ solution induced high levels of fusion, and demonstrated that protoplasts from different species (Avena sativa and Zea mays) could be made to fuse together with this treatment. These studies did not investigate protoplast regeneration, but $\mathrm{NaNO}_{3}$ was employed to induce protoplast fusion in the experiment which led to the first reported recovery of a somatic hybrid plant, between two species of tobacco, Nicotiana glauca and $\mathcal{N}$. langsdorffi (Carlson et al., 1972; 
see below). In many systems, $\mathrm{NaNO}_{3}$ did not appear to be effective in the large-scale production of viable fusion products, and alternative treatments were sought. Of these, $\mathrm{Ca}^{++}$at high $p \mathrm{H}$ (Keller and Melchers, 1973) and polyethyleneglycol (Kao and Michayluk, 1974; Wallin et al., 1974) proved to be most generally useful, and most protoplast fusions are now carried out using a combination of these treatments. Kao et al. (1974), for example, induced fusion by first treating isolated protoplasts with polyethyleneglycol and then diluting them with a solution of $50 \mathrm{~mm} \mathrm{CaCl}_{2}$ buffered to $\mathrm{pH} 10 \cdot 5$. Essentially similar methods have been employed in many other studies reported subsequently. The various fusion treatments which have been devised probably have in common that they combined a method of overcoming the repulsive forces on the protoplast surface, so that intimate contact can occur between protoplasts, with the induction of minor local damage to the plasmolemma, allowing membrane fusion to begin, thus leading to the formation of a hybrid cell.

Since, in general, fusion techniques have been developed in order to obtain a hybrid product which has arisen from the fusion of a single protoplast from one strain with another from a second strain, most fusion protocols have been designed to maximise such products, usually by regulating carefully the ratio of the protoplasts of different origins and by adjusting the concentration of protoplasts treated so as to avoid multiple fusions. Nevertheless, most techniques employed give rise, in addition, to products of the fusion of more than two protoplasts, as well as to fusions involving only one of the two types of protoplast used. Various methods have been suggested which would minimise the latter intra-strain fusions. Melchers (1977a) describes work in progress to attempt to give the protoplasts to be fused opposite charges, but reports no success, and it is possible that the work of Larkin $(1977,1978 a, b)$ on protoplast agglutination might lead to some technique for the maximisation of interstrain fusion.

\section{(iv) The recognition and selection of hybrid products}

If somatic hybrids are to be obtained by way of protoplast fusion, it is obviously desirable to be able to recognise hybrid cells as early as possible after fusion. One approach which has been consistently successful in both early and more recent studies is to use morphologically distinct protoplasts. Thus Michel (1937) used material with differing anthocyanin contents and was thereby able to identify directly fusion events involving protoplasts of different origins. This approach has the disadvantage that the choice of material is dictated by its cellular morphology rather than by its suitability for protoplast isolation and regeneration. These considerations are not necessarily incompatible, but in many cases result in a choice of material, protoplasts from which are difficult to regenerate. Where, nevertheless, recognisably-hybrid products do regenerate, it is necessary to isolate these from other regenerated material, usually by micromanipulation. This technique has recently been used successfully to obtain hybrid cell lines between, for example, Glycine max and Nicotiana glauca (Kao, 1977), Vicia faba and Petunia hybrida (Binding and Nehls, 1978), Arabidopsis thaliana and Brassica campestris (Gleba and Hoffman, 1978), Atropa belladonna and Petunia hybrida (Gosch and Reinhardt, 1978) and Nicotiana knightiana and $\mathcal{N}$. sylvestris (Menczel et al., 1978). In all these cases, the hybrid origin of the cell line 
was confirmed either by the pattern of isoenzyme production or by karyotype analysis (but see section 4 below for more details). Where morphologically distinct protoplasts are not available, or where a low frequency of regeneration makes micromanipulation too burdensome, attempts have been made to devise selective procedures in which the protoplast mixture is cultured, after suitable fusion treatment, in conditions chosen so as to discourage parental and to favour hybrid growth. This end has, however, been achieved in a variety of different ways.

The first approach to be used successfully exploited known differences in the growth substance requirements of cell cultures on the one hand of the two species to be fused and on the other of the sexual hybrid between them. Thus Carlson et al. (1972) plated a mixture of protoplasts from Nicotiana glauca and $\mathcal{N}$. langsdorffi, after treatment in $\mathrm{NaNO}_{3}$ solution to promote fusion, on to a medium containing low concentrations of growth substances (3 mg/l l-naphthaleneacetic acid; $1 \mathrm{mg} / \mathrm{l}$ 6-benzylaminopurine; Nagata and Takebe, 1971) upon which it was known that protoplasts from neither species could regenerate, but that protoplasts from the sexual hybrid between these species could. A number of callus cultures developed and one of these was induced to regenerate and form a plant which was found to be morphologically similar to the sexual hybrid. Although some doubt has been cast on whether this plant did in fact originate by protoplast fusion (Melchers, $1977 a$ ), the method is certainly valid, and has been used subsequently to isolate large numbers of somatic hybrids from mixtures of protoplasts from these two Nicotiana species (Smith et al., 1976). An essentially similar procedure has been employed to obtain somatic hybrids of Petunia hybrida and P. parodii (Power et al., 1976, 1977).

A number of selective techniques have been devised which exploit complementing mutant strains. Schieder (1974) selected a hybrid of the liverwort, Sphaerocarpus donnellii, following treatment with $\mathrm{Ca}^{++}$and high $p \mathrm{H}$ of a mixture of protoplasts from two mutant strains, one of which was auxotrophic for nicotinic acid, and the other of which was pale green, requiring glucose for growth. The hybrid was both prototrophic and autotrophic, having diploid gametophytic nuclei containing the full chromosome complement of both component strains. Complementing auxotrophic mutant strains have also been used widely in the selection of both intra- and interspecific hybrids in the fungi. Fungal species in which intraspecific hybrids have been selected by this means include Geotrichum candidum (Ferenczy et al., 1974), Phycomyces blakesleeanus (Binding and Weber, 1974), Aspergillus nidulans(Ferenczy et al., 1975a, b), Penicillium chrysogenum (Anné and Peberdy, 1975), Schizosaccharo myces pombe (Sipiczki and Ferenczy, 1977a), Rhodosporidium toruloides (Sipiczki and Ferenczy, 1977b), Saccharomyces cerevisiae (Ferenczy and Maráz, 1977; Svoboda, 1977), S. lipolytica (Stahl, 1978) and Cephalosporium acremonium (Hamlyn and Ball, 1979). The same method has been employed to isolate various interspecific hybrids between fungal species. These include Penicillium chrysogenum with $P$. notatum (Anné and Peberdy, 1976), P. chrysogenum with $P$. roquefortii (Anné et al., 1976), $P$. chrysogenum with $P$. cyaneo-fulvum (Peberdy et al., 1977), Aspergillus nidulans with A. rugulosus (Kevei and Peberdy, 1977) and A. nidulans with $A$. fumigatus (Ferenczy et al., 1977). The nature of the hybrid product obtained varied depending on the species involved, but in all cases its gross morphology resembled that of the species involved. Most of the intraspecific hybridisations gave rise to either stable 
heterokaryons or stable diploids, but no clear evidence for either diploid or heterokaryon formation was obtained for Cephalosporium acremonium, where the selected products of protoplast fusion appear to be haploid, with recombinant genotypes. Interspecific hybrids were in general less stable than intraspecific hybrids and it is probable that some at least were aneuploids.

Because auxotrophic mutant strains of green plants are not so widely available, they have been of less use for hybrid selection. However, they have been used to obtain hybrids, following protoplast fusion, in the moss, Physcomitrella patens (Grimsley et al., 1977a,b). By plating treated mixtures of protoplasts from complementary auxotrophic strains directly on to selective medium, hybrid plants were obtained which had a stable phenotype. Although there is no cytological evidence for the nature of the hybrids obtained, their genetic behaviour following self-fertilisation was consistent with their having diploid gametophytes. In an essentially similar way hybrid cell lines have been obtained from mixtures of protoplasts or " miniprotoplasts" (Wallin et al., 1978) from two mutant allodihaploid cell lines of Nicotiana tabacum, neither of which was able to utilise nitrate as a nitrogen source (Glimelius et al., 1978; Müller and Grafe, 1978; Wallin et al., 1979). A mixture of protoplasts was plated, following a fusion treatment, firstly on to a non-selective medium in which a mixture of amino acids served as nitrogen source; the growing cells were then transferred after 10 days to a selective medium where nitrate was the nitrogen source. By this means a large number of cell lines able to utilise nitrate was obtained, some of which have been investigated cytologically and have been found to contain nuclei having a range of chromosome numbers higher than that of either of the component strains. It has also been possible to induce shoot formation on some of the selected cell lines, a property which the original mutant cell lines had lost.

The use of mutant strains with photosynthetic abnormalities has been a more successful approach in higher plant systems. Melchers and Labib (1974) were the first to exploit such material using strains of $\mathcal{N}$ icotiana tabacum which were not only chlorophyll-deficient but also sensitive to high light intensities. Protoplasts were obtained from allodihaploid derivatives of two chlorophyll-deficient lines, known by sexual crossing to complement in the $\mathrm{F}_{1}$ and, following a fusion treatment, were plated on to a medium and grown under culture conditions such that both parental strains produced pale green calli. Hybrid calli were identified because they were dark green, and it subsequently proved possible to regenerate plants from these hybrid cell lines which resembled the hybrid produced by sexual crossing. An essentially similar procedure has been used to obtain hybrid plants between two strains of Datura innoxia (Schieder, 1977a) and between Petunia hybrida and P.parodii (Cocking et al., 1977).

An extension of the use of chlorophyll-deficient strains involves the fusion of protoplasts from such a strain with protoplasts from the wild type, the mixture being cultured subsequently under conditions which allow the regeneration of protoplasts from the chlorophyll-deficient strain, but not of those of the wild type. Hybrid cell lines are identified because they are able to grow, and are green. This technique has been used to obtain interspecific hybrid cell lines between Nicotiana knightiana and $\mathcal{N}$. sylvestris (Maliga et al., 1977) and between $\mathcal{N}$. knightiana and $\mathcal{N}$. tabacum (Maliga et al., 1978). In both these cases, the hybrid cell lines produced shoots when cultured under 
conditions in which neither component strain possessed this property. The same technique has also been used to obtain interspecific hybrid plants between Daucus carota and D. capillifolius (Dudits et al., 1977) and between Datura innoxia and $D$. discolor, and $D$. innoxia and $D$. stramonium (Schieder, $1978 a, b)$.

Various workers have experimented with naturally-occurring differential drug sensitivity as a basis for hybrid selection (Cocking et al., 1974; Maliga et al., 1977) and it is likely that more use of this will be made in the future. It is envisaged that drug resistant strains for use in hybrid selection procedures will also be isolated following mutagenic treatment (Maliga, 1978).

An entirely different selective procedure for the isolation of hybrid cells following protoplast fusion has been devised by Harms and Potrykus (1978a, b). This technique exploited differences in buoyant density between protoplasts to be fused. The treated mixtures of protoplasts was placed on to the top of an iso-osmotic, stepped-density gradient (Harms and Potrykus, 1978b) and centrifuged. Where the buoyant densities of protoplasts of the two component strains were sufficiently different and the protoplasts from each strain moved to different interfaces on the stepped-density gradient, then the fraction collected from the interface $(s)$ between those where the component strains sedimented was found to be enriched for protoplasts originating from interstrain fusion events. The technique does not appear to affect the viability of protoplasts and has been shown to be effective in hybrid selection using complementary chlorophyll-deficient $\mathcal{N}$ icotiana tabacum strains as test material. It should therefore have considerable potential use where other selective techniques are not available.

\section{The USES OF SOMATIC HYBRIDISATION}

\section{(i) The bypassing of sexual incompatibility}

The most frequently quoted potential use of the technique of protoplast fusion is the isolation of hybrids which it is not possible to obtain by normal sexual means, in the hope that these might provide useful material, particularly for plant breeding. Although a number of hybrid cell lines have been obtained following protoplast fusion, involving combinations of species which it has not been possible to hybridise sexually, it appeared until recently that, at least as far as higher plants were concerned, it would only be possible to obtain hybrid plants by protoplast fusion which were also obtainable by sexual means. This implies that although protoplast fusion overcomes incompatibilities associated with the process of sexual reproduction, these are not necessarily the fundamental barriers to the obtaining of interspecific hybrids. Zentkeler and Melchers (1978) pointed out that the barriers which protoplast fusion can overcome can often also be overcome by modifying the normal process of sexual reproduction by manipulations, such as the in vitro pollination of ovules. However, recently the first reports have appeared of the isolation of plants from hybrid cell lines obtained by means of protoplast fusion, involving species which have not, thus far at least, been hybridised by sexual means. These include Lycopersicum esculentum and Solanum tuberosum (Melchers et al., 1978), Daucus carota and Agopodium podagraria (Dudits et al., 1979), Datura innoxia and Atropa belladonna (although here, shoots rather than whole plants have been obtained) (Krumbiegel and Schieder, 1979) and 
Arabidopsis thaliana and Brassica campestris (Gleba and Hoffman, 1979). In the latter case, at least some of the regenerant plants had a morphology recognisably intermediate between the two species hybridised, but most were morphologically abnormal, and some hybrid cell lines gave rise to plants with a wide range of morphologies. It is likely that some, and perhaps most, of this heterogeneity is correlated with variations in the chromosome numbers of the hybrids. Gleba and Hoffman $(1978,1979)$ report that this varied considerably both in the hybrid cell lines and in the plants regenerated from them. Variable chromosome number appears to be a feature of most higher plant somatic hybrids (see Melchers and Sacristán, 1977; Chupeau et al., 1978; for studies investigating this specifically). However, Sacristán and Melchers (1969) had earlier shown that plants regenerated from callus cultures also had variable chromosome numbers. It is therefore likely that much of the variability in chromosome number observed in somatic hybrids is a result of the regeneration of plants from cell cultures, rather than being due to the protoplast fusion procedure per se. Nevertheless, protoplast fusion certainly allows the selection of hybrids following fusion events involving more than two cells, and these must always remain a potential source of variation. It is difficult to see how this problem can be overcome. The direct regeneration of a plant from a protoplast, as is possible in fungi and mosses, would bypass variability arising during the callus stage, but it seems extremely unlikely that this could be achieved in higher plants, and so the only procedure available appears to be the regeneration of as large a number as possible of hybrid plants from a large number of independently isolated hybrid cell lines, in order to assess the range of hybrid phenotypes available. It is anyhow unlikely that hybrids between distantly related species will be capable of orderly development, and it may be that, if the object of hybridisation is to transfer only certain specific characters from one species to another, a hybrid possessing all the chromosomes of both species is neither necessary nor desirable.

Interspecific hybridisation involving fungal species have already been referred to in section 3 (iv) above. Here again the hybrids are often unstable, and spontaneous chromosome loss may occur, or may even be induced by agents such as chloral hydrate or benomyl (methyl-1-(butylcarbamoyl)-2benzimidazole carbomate) (Kevei and Peberdy, 1979). However, this is not necessarily a disadvantage, as the end product may be a stable strain having a recombinant haploid genotype. Hybrid genotypes produced by protoplast fusion are therefore likely to be of considerable use in the development of economically-important fungal strains, especially where the species concerned do not normally undergo sexual reproduction, although it should be borne in mind that alternative parasexual methods of hybridisation are available for many fungal species.

\section{(ii) The bypassing of sexual sterility}

One use to which somatic hybridisation, by protoplast fusion, is already being put is the genetic analysis of mutant strains which are sexually sterile because of developmental abnormality. Since sexual reproduction can in some ways be regarded as the end product of development, it is not surprising that strains blocked particularly at an early stage of development are likely to be sexually sterile. This is especially a problem where the development 
of the haploid phase of the life cycle of a species is being studied, or where the developmental abnormality is the result of the possession of a mutant allele whose effect is dominant to that of the wild type. In the latter case, the chromosome instabilities encountered in hybrid cell lines, and in plants regenerated from them, may be of positive advantage as it may be possible to use methods essentially similar to those already used in animal somatic cell genetics (Ruddle and Creagan, 1975) and correlate particular phenotypes with the possession of particular chromosomes.

In studies of the development of the gametophyte of the moss, Physcomitrella patens, a wide range of developmentally abnormal mutant strains has been isolated, most of which are sexually sterile (Ashton and Cove, 1977; Ashton et al., 1979a, $b$ ). Genetic analysis of these mutants has been possible as a result of the production of somatic hybrids obtained following protoplast fusion. Hybrids were selected by the inclusion of complementing auxotrophic mutant alleles in the strains to be hybridised (Grimsley et al., 1977a, $b$; Ashton et al., 1979a). The hybrids can then be used to test for complementation between mutant alleles leading to a developmentally-abnormal phenotype, which may be present in the two component strains, and the genetic complexity of a developmental stage can thus be investigated. It is first necessary to establish that any such mutant alleles are recessive to the wild type, and this can be determined by the production of somatic hybrids between the developmentally-abnormal strain and a developmentally-normal (but auxotrophic) strain. These hybrids can also be used to decide whether a single mutation is likely to be responsible for the developmentally-abnormal phenotype, by studying the segregation observed among progeny arising from self-fertilisation of the hybrid. The ratios which have been obtained in such crosses are consistent with hybrids having a diploid gametophyte and hence a tetraploid sporophyte (Grimsley et al., 1977a). The most extensive analysis of developmentally-abnormal mutants using somatic hybridisation which has been carried out so far involves extreme gametophoreoverproducing mutants (Ashton et al., 1979b). Featherstone (unpublished data) has shown that a sample of 17 mutants of this type involves at least three complementation groups, and self-fertilisation of hybrids has established in two cases that a single mutation is likely to lead to the mutant phenotype.

No other extensive studies of a similar type have been reported, but it is to be envisaged that such studies will become more common. A related use would be the investigation of the genetic basis of metabolically-abnormal cell lines. Here somatic hybridisation may be necessary where the cell lines cannot be regenerated into plants as appears to be the case with the nitratenon-utilising lines of Nicotiana tabacum (Glimelius et al., 1978; Müller and Grafe, 1978). Even where regeneration to form sexually fertile plants is possible, it may be that hybridisation by means of protoplast fusion will be a quicker and simpler method of complementation analysis.

\section{(iii) The study of cytoplasmic inheritance}

In most species, a hybrid cell produced by the fusion of two protoplasts will differ from a zygote, in that it will contain a more or less equal amount of cytoplasm, and hence organelles, from the two parental strains. Protoplast fusion therefore provides a unique opportunity for the study of cytoplasmic inheritance in higher plants. A variety of hybrid products may result from 
protoplast fusion. Hybrids may contain not only the nuclear genomes but also the cytoplasmic genomes of the two parental strains. Alternatively, they may contain cytoplasm derived from both strains, but the nuclear genome of one only (Cocking (1977) has suggested the term "cybrid" for such a hybrid), or they may show no evidence for cytoplasmic or nuclear heterogeneity, but nevertheless have novel combinations of cytoplasmic and nuclear genomes. Gleba (1979) has provided evidence that all these types of hybrid product can be obtained by way of protoplast fusion. His investigations utilised an albino strain of Nicotiana tabacum which showed a cytoplasmic pattern of inheritance and which was known to have abnormal plastid DNA, and a yellow strain homozygous for a nuclear mutation leading to chlorophyll deficiency. In this way both nuclear and plastid genomes were marked, and their inheritance could be studied independently in somatic hybrids. Chen et al. (1977) have also provided evidence that somatic hybrids obtained by protoplast fusion may contain plastid-coded information derived from both parents. These workers obtained somatic hybrids between Nicotiana glauca and $\mathcal{N}$. langsdorffi and studied the pattern of production of the large subunit polypeptides of fraction 1 protein (ribulose-1,5-diphosphate carboxylase/ oxygenase) which is known to be coded for by chloroplast DNA. The two species produce distinguishable large subunit polypeptides, and it was possible to show that some hybrid cell lines and a plant derived from one produced a mixture of the two types of large subunit. However, in most cases hybrids contained only one or the other of the two large subunit types, and so there appears to be a rapid sorting out process leading to the production of cells containing only one type of plastid, a situation reminiscent of the behaviour of mitochondria in yeast diploids (Wilkie and Thomas, 1973). The experiments of Belliard et al. (1978) support this conclusion. Where suitably marked stocks are available, studies of this kind provide the opportunity to investigate whether or not recombination between plastid genomes can occur in higher plants. Gleba (1979) describes experiments aimed at this, although he detects no recombination. Experiments have also been initiated using protoplast fusion with Nicotiana species in order to study cytoplasmically-inherited male sterility (Belliard et al., 1977, 1978; Gleba, 1979). Insufficient results have been obtained so far to shed further light on the genetic basis of this type of male sterility.

It should be equally possible to study mitochondrial genetics in higher plants using these techniques, and although this branch of genetics is already well established in the fungi, the production of hybrids by protoplast fusion allows such work to be extended to fungal species and strains where naturally occurring methods of cytoplasmic hybridisation are not available or have been lost (Ferenczy and Maráz, 1977; Allmark et al., 1978).

Although hybridisation by way of protoplast fusion has so far proved to be the most promising approach to the study of organelle genetics in plants, there have been a number of studies aimed at approaching this problem in a rather different way. These involve either the fusion of protoplasts with subprotoplasts (i.e., protoplasts having no nuclei) (Binding and Kollman, 1976; Binding, 1979) or the uptake of isolated organelles by protoplasts. Carlson (1973) reported the regeneration of Nicotiana tabacum plants containing green chloroplasts from protoplasts derived from a cytoplasmicallyinherited albino mutant which had been treated with chloroplasts from the wild-type. Although no experimental details are given, it appears no specific 
treatment aimed at maximising chloroplast uptake was incorporated and no details of control treatments are included. In a subsequent study a single variegated plant was isolated by Kung et al. (1975) following treatment of protoplasts from a cytoplasmically-inherited albino strain of Nicotiana tabacum with chloroplasts isolated from a green strain of $\mathcal{N}$. suaveolens. Green calli arose from regenerating protoplasts at an approximate rate of $2.0 \times 10^{-4}$ compared with the control rate (presumably from albino protoplasts untreated with chloroplasts) of $10^{-8}$. The majority of these green calli failed to regenerate into plants. The single plant obtained had an average chromosome number of 64, compared with 48 in $\mathcal{N}$. tabacum and 32 in $\mathcal{N}$ suaveolens. Analysis of the fraction 1 protein produced by the variegated plant showed that polypeptides characteristic of both $\mathcal{N i c o t i a n a}$ species were produced; however, these included not only chloroplast DNA-coded polypeptides but also those known to be coded for by nuclear DNA. Kung et al. (1975) therefore suggested that the hybrid must have been derived from a protoplast which had taken up not only chloroplasts from $\mathcal{N}$. suaveolens but also an isolated nucleus. Nuclei were known to be a contaminant of the chloroplast preparations. These studies appear to remain the only reports of the isolation of plants derived from protoplasts which have taken up chloroplasts, although other studies on chloroplast uptake by protoplasts have been carried out (Potrykus, 1973, 1975; Uchimiya, 1979), including the uptake of chloroplasts from Spinacea oleracea into protoplasts from the fungus, Neurospora crassa (Vasil and Giles, 1975), and of chloroplasts from the alga, Vaucheria dichotoma, into protoplasts of Daucus carota (Bonnett and Eriksson, 1974).

The uptake and incorporation of isolated mitochondria into protoplasts of Saccharomyces cerevisiae has been reported recently (Gunge and Sakaguchi, 1979). In these studies the isolated protoplasts and mitochondria were mixed and treated with polyethyleneglycol in the presence of $10 \mathrm{mM} \mathrm{CaCl}_{2}$, and then spread on to a selective medium such that only protoplasts which had incorporated the donor mitochondria could regenerate and grow. It was found that such recombinants arose at a low frequency.

Because of the importance of mitochondria and chloroplasts in the energy metabolism of plants, it is clear that techniques which allow the manipulation of their genomes are likely to be of economic significance as well as being valuable in extending our knowledge in this important area of genetics.

\section{Other USES OF ISOlATED PROTOPLASTS IN PLANT GENETICS}

(i) Protoplasts as material for mutagenic treatment

Although they have not as yet been exploited widely for this purpose, isolated protoplasts should provide excellent material for mutagenic treatment. By the choice of suitable starting material it is possible to get uniform preparations of large numbers of protoplasts, which can be plated so as to obtain clones each derived from a single protoplast. Protoplasts are therefore likely to be superior to either cell cultures or tissue homogenates, both of which suffer from containing multicellular material which cannot be separated. Grimsley (1978) reports preliminary experiments with protoplasts isolated from young protonemal tissue from Physcomitrella patens, using either ultraviolet light, or ethyl methane sulphonate, or $\mathcal{N}$-methyl- $\mathcal{N}$ '-nitro- 
$\mathcal{N}$-nitrosoguanidine as mutagen. This work is being continued by Featherstone and Wang (unpublished data), who are attempting to isolate mutations leading to cytokinin overproduction in a strain auxotrophic for adenine. This strain is self-sterile and so that the usual source of material for mutagenic treatment in $P$. patens, spores from sporophytes which have developed following self-fertilisation, is not available, illustrating another reason why protoplasts may be the material of choice for mutagenic treatment. These experiments, in which protoplast suspensions are irradiated with ultraviolet light, have proceeded far enough to indicate that yields of developmentallyabnormal mutant strains are likely to be similar to those obtained in comparable experiments using spores as the treated material, but no quantitative datum is yet available.

Bourgin (1978) has selected valine-resistant Nicotiana tabacum plants, using protoplasts as the material for mutagenic treatment. Protoplasts were isolated from mesophyll tissue from an allodihaploid strain, and regenerated to form small cell colonies, which were then plated on to valine-containing medium. Plants were regenerated from calli which developed on the selective medium, some of which proved to be resistant to valine. The value of protoplasts for material for mutagenic treatment has therefore been established, and it is to be envisaged that protoplasts will be used for this purpose more extensively.

\section{(ii) Protoplasts and the uptake of foreign genetic material}

Isolated plant protoplasts take up a variety of foreign material which is not normally taken up by cells with intact walls. Uptake of quite large particles can occur, including chloroplasts, mitochondria (see section 4 (iii) above) and polystyrene spheres up to $0.3 \mu \mathrm{m}$ in diameter (Cocking, 1970). Suzuki et al. (1977) have provided evidence that uptake of polystyrene spheres by isolated Nicotiana tabacum protoplasts is likely to involve active endocytosis, rather than to occur as a consequence of local damage to the plasmalemma, as had been suggested earlier to account for the entry of viruses into protoplasts (Burgess et al., 1973a,b). Uptake of the bacterium, Rhizobium leguminosarum, by Pisum sativum protoplasts has also been achieved (Davey and Cocking, 1972) by including bacteria in the enzyme mixture in which leaf material was treated in order to isolate protoplasts. Potrykus and Hoffman (1973) have also demonstrated that protoplasts can take up isolated nuclei, and Lurquin and Kado (1977) have shown that protoplasts isolated from mesophyll tissue of Vigna sinensis take up Escherichia coli plasmid pBR313 DNA into their nuclei. These latter studies, whilst clearly having the potential, have not yet been exploited for genetic ends (see Cocking, 1977; Giles, 1978, for reviews).

Protoplasts have, however, been utilised in recent studies in which yeast strains have been transformed with exogenous DNA. Although the earliest report of successful transformation of a eukaryotic species (Neurospora crassa) did not involve the use of protoplasts (Mishra et al., 1973), these have been employed by three groups of workers who have demonstrated transformation in Saccharomyces cerevisiae (Beggs, 1978; Hinnen et al., 1978; Gerbaud et al., 1979). In each of these cases, yeast protoplasts have been treated with DNA which has been enriched for specific gene regions by the techniques of genetic engineering. The DNA was added to protoplasts, and the mixture treated 
with polyethylene glycol in the presence of $\mathrm{Ca}^{++}$ions. These authors make little reference to the rationale behind this choice of material or treatment used, nor do they report experiments which led to their optimisation. However, polyethyleneglycol had been shown previously to stimulate not only protoplast fusion, but also the uptake of chloroplasts (Bonnett and Eriksson, 1974). It is not yet clear, however, whether this effect on uptake is brought about directly as a result of the induction of local damage to the plasmalemma, or whether DNA uptake occurs as a result of molecules being trapped between protoplasts which are involved in fusion events, possibly of a transient nature. The fate of the DNA taken up in these transformation experiments has been followed by crossing the transformed strains. Hinnen et al. (1978) report the recovery of a variety of classes of transformant. In most, the complete DNA sequence used for transformation, which included not only the DNA sequence containing the wild-type leu 2 allele derived from yeast, but also the Escherichia coli plasmid Col E1 sequence, was integrated into chromosome III adjacent to the leu 2 gene, thus duplicating this region. In other transformants, the foreign DNA appeared to have become in tegrated at an alternative chromosomal site, whilst in one transformant neither the $E$. coli plasmid DNA, nor the recipient leu2- allele appeared to be present, the donor $l e u^{+}$DNA apparently having been substituted for the leu2- mutant allele. Beggs (1978), in contrast, reports non-nuclear inheritance of the transformed character, indicating that in this case integration at a chromosomal site has not occurred.

\section{Discussion}

Until recently, it appeared that those who had suggested that protoplasts provided material which would lead to major break-throughs in a number of areas of plant genetics, were being more optimistic than the results obtained with protoplasts warranted. Whilst the achievements directly due to the use of protoplasts remain limited, results obtained recently do indicate that protoplasts will not represent a technology without a use. They are likely to be valuable as tools for hybridisation, and particularly in bringing about the transfer of fragments of genomes, both nuclear and cytoplasmic. Their full potential in a number of other fields of genetics, including for example mutagenesis, is yet to be realised, and they are likely to continue to be valuable in less genetically relevant areas, not covered by this review, such as virus infection and cell fractionation (see for example, Ohyama et al., 1977).

\section{REFERENCES}

ALLMARK, B. M., MORGAN, A. J., AND WHTTTAKER, P. A. 1978. The use of protoplast fusion in demonstrating chromosomal and mitochondrial inheritance of respiratory-deficiency in Kluyveromyces lactis, a petite-negative yeast. Molec. gen. Genet., 159, 297-299.

ANNÉ, J., AND PEBERDY, J. F. 1975. Conditions of induced fusion of fungal protoplasts in polyethylene glycol solutions. Arch. Microbiol., 105, 201-205.

ANNÉ, J., AND PEBERDY, J. F. 1976. Induced fusion of fungal protoplasts following treatment with polyethylene glycol. 7. gen. Microbiol., 92, 413-417.

ANNÉ, J., EYSSEN, H., AND DE SOMER, P. 1976. Somatic hybridization of Penicillium roquefortii with $P$. chrysogenum after protoplast fusion. Nature (Lond.), 262, 719-721.

ASHTON, N. W., AND COVE, D. J. 1977. The isolation and preliminary characterisation of auxotrophic and analogue resistant mutants of the moss, Physcomitrella patens. Molec. gen. Genet., 154, 87-95. 
ashton, N. w., COVE, D. J., AND featherstone, D. R. 1979b. The isolation and physiological analysis of mutants of the moss, Physcomitrella patens, which over-produce gametophores. Planta, 144, 437-442.

Ashton, N. W., GRIMSley, N. H., AND COVE, D. J. 1979a. Analysis of gametophytic development of the moss, Physcomitrella patens, using auxin or cytokinin resistant mutants. Planta, 144, 427-435.

BAChmanN, B. J., AND bONNER, D. м. 1959. Protoplasts from Neurospora crassa. 7. Bacteriol., $78,550-556$.

BANKS, M. s., AND EVANs, P. K. 1976. A comparison of the isolation and culture of mesophyll protoplasts from several Nicotiana species and their hybrids. Plant Science Letters, 7, 409. 416.

BEGGS, J. D. 1978. Transformation of yeast by a replicating hybrid plasmid. Nature (Lond.), 275, 104-109.

belliard, G., PElletier, G., aNd ferault, M. 1977. Fusion de protoplastes de Nicotiana tabacum à cytoplasmes différents: étude des hybrides cytoplasmiques néo-formés. C.R. Acad. Sci. Paris, Series D, 284, 749-752.

Belliard, G., PElletier, G., Vedel, F., AND Quetier, F. 1978. Morphological characteristics and chloroplast DNA distribution in different cytoplasmic parasexual hybrids of Nicotiana tabacum. Molec. gen. Genet., 165, 231-237.

BHoJWANI, s. s., EVANs, P. K., AND CockING, E. C. 1977. Protoplast technology in relation to crop plants : progress and problems. Euphytica, 26, 343-360.

BINDING, H. H. 1966. Regeneration und Verschmelzung nackter Laubmoos protoplasten. Z. Pflanzenphysiol., 55, 305-321.

BINDING, H. 1979. Subprotoplasts and organelle transplantation. Plant Cell and Tissue Culture. Principles and Applications, eds. W. R. Sharp, P. O. Larsen, E. F. Paddock and V. Raghavan. Ohio State University Press, Ohio.

BINDiNG, H., AND KOlLMAN, R. 1976. The use of subprotoplasts for organelle transplantation. Cell Genetics in Higher Plants, eds. D. Dudits, G. L. Farkas and P. Maliga, pp. 191-206. Akadémiai Kiadó, Budapest.

BINDING, H., AND NEHLs, R. 1978. Somatic cell hybridization of Vicia faba and Petunia hybrida. Molec. gen. Genet., 164, 137-143.

BINDING, H., AND WEBER, H. J. 1974. The isolation, regeneration and fusion of Phycomyces protoplasts. Molec. gen. Genet., 135, 273-276.

BONNETT, T., AND ERIKSSON, T. 1974. Transfer of algal chloroplasts in to protoplasts of higher plants. Planta, 120, 71-79.

Bourgin, J.-P. 1978. Valine-resistant plants from in vitro selected tobacco cells. Molec. gen. Genet., 161, 225-230.

BRENNER, s., DARK, F. A., GerHARdT, P., JEYNEs, M. H., KANDLER, O., Kellenberger, E., KLEINEBERGER-NOBEL, E., MGQUILlAN, K., RUBIO-HUERTES, M., SALTON, M. R. J., STRANGE, R. E., TOMEsik, J., AND Weibull, c. 1958. Bacterial protoplasts. Nature (Lond.), 181, 1713-1715.

BURGESS, J., MOTOYOSHI, F., AND FLEMING, E. N. 1973a. Effect of poly-L-ornithine on isolated tobacco mesophyll protoplasts: Evidence against stimulated pinocytosis. Planta, 111, 199-208.

BURGESS, J., MOTOYOSHI, F., AND FLEMING, E. N. 1973b. The mechanism of infection of plant protoplasts by viruses. Planta, 112, 323-332.

CARlson, P. s. 1973. The use of protoplasts for genetic research. Proc. natl. Acad. Sci. U.S.A., $70,598-602$.

Carlson, P. s., smith, H. H., AND Dearing, R. 1972. Parasexual interspecific plant hybridization. Proc. natl. Acad. Sci. U.S.A., 69, 2292-2294.

Chambers, R., AND höfler, K. 1931. Micrurgical studies on the tonoplast of Allium cepa. Protoplasma, 12, 338-355.

CHEN, K., WILDMAN, s. G., AND SMTTH, H. H. 1977. Chloroplast distribution in parasexual hybrids as shown by polypeptide composition of fraction I protein. Proc. natl. Acad. Sci. U.S.A., 74, 5109-5112.

GHUPEAU, Y., MISSONIER, C., HOMME L, M.-G., AND GOUJAUD, J. 1978. Somatic hybrids of plants by fusion of protoplasts. Observations on the model system " Nicotiana glauca-Nicotiana langsdorffi ". Molec. gen. Genet., 165, 239-245.

Cocking, E. C. 1960. A method for the isolation of plant protoplasts and vacuoles. Nature (Lond.), 187, 962-963.

COCKING, E. c. 1970. Virus uptake, cell wall regeneration and virus multiplication in isolated plant protoplasts. International Review of Cytology, 28, 89-124. 
COCKING, E. C. 1977. Uptake of foreign genetic material by plant protoplasts. International Review of Cytology, 48, 323-343.

Cocking, E. c. 1978. Selection and somatic hybridisation. Frontiers of Plant Tissue Culture, 1978, ed. T. A. Thorpe, pp. 151-158. The International Association for Plant Tissue Culture, Calgary.

COCKING, E. C., GEORGE, D., PRICE-JONES, M. J., AND POWER, J. B. 1977. Selection procedures for the production of inter-species somatic hybrids of Petunia hybrida and Petunia parodii II. Albino complementation selection. Plant Science Letters, 10, 7-12.

COCKING, E. C., POWER, J. B., EVANS, P. K., SAFWAT, F., FREARSON, E. M., HAYWARD, C., BERRY, s. F., AND GEORGE, D. 1974. Naturally occurring differential drug sensitivities of cultured plant protoplasts. Plant Science Letters, 3, 341-350.

ConstaBeL, F. 1978. Development of protoplast fusion products, heterokaryocytes and hybrid cells. Frontiers of Plant Tissue Culture, 1978, ed. T. A. Thorpe, pp. 141-149. International Association for Plant Tissue Culture, Calgary.

DAVEY, M. R., AND COCKING, E. C. 1972. Uptake of bacteria by isolated higher plant protoplasts. Nature (Lond.), 239, 455-456.

DUDITS, D., HADLACZKY, GY., LÉvi, E., FEJÉR, O., HAYdu, z. s., AND LÁzÁR, G. 1977. Somatic hybridisation of Daucus carota and $D$. capillifolius by protoplast fusion. Theor. appl. Genet., 51, 127-132.

DUDiTs, D., HADLACZKY, GY., BAJSKÁR, G. Y., KONCZ, CS., LÁZÁR, G., AND HORVÁth, G. 1979. Plant regeneration from intergeneric cell hybrids. Plant Science Letters, 15, 101-112.

EDDY, A. A., AND williamson, D. H. 1957. A method of isolating protoplasts from yeast. Nature (Lond.), 179, 1252-1253.

EMERson, s. 1963. Slime. A plasmodioid variant of Neurospora crassa. Genetica, 36, 162.

EMERSON, s., AND EMERSON, M. R. 1958. Production and reversion of protoplast-like structures in the osmotic strain of Neurospora crassa. Proc. natl. Acad. Sci. U.S.A., 44, 668-671.

ERIksson, T. 1977. Technical advances in protoplast isolation and cultivation. Plant Tissue Culture and its Bio-technological Application, eds. W. Barz, E. Reinhard and M. H. Zenk, pp. 313-322. Springer, Berlin, Heidelberg and New York.

ERIKsson, T., GLImelius, K., AND WAllin, A. 1978. Protoplast isolation, cultivation and development. Frontiers of Plant Tissue Culture, 1978, ed. T. A. Thorpe, pp. 131-139. The International Association for Plant Tissue Culture, Calgary.

ERIKSSON, T., AND JONASSON, K. 1969. Nuclear division in isolated protoplasts from cells of higher plants grown in vitro. Planta (Berl.), 89, 85-89.

FERENCZY, L., KEVEI, F., AND SZEGEDI, M. 1975a. Increased fusion frequency of Aspergillus nidulans protoplasts. Experientia, 31, 50-52.

FERENCZY, L., KEVEI, F., AND SZEGEDI, M. 1975b. High-frequency fusion of fungal protoplasts. Experientia, 31, 1028-1030.

FERENCZY, L., KEVEI, F., AND zSOLT, J. 1974. Fusion of fungal protoplasts. Nature (Lond.), 248, 793-794.

FERENCZY, L., AND MARÁz, A. 1977. Transfer of mitochondria by protoplast fusion in Saccharomyces cerevisiae. Nature (Lond.), 268, 524-525.

FERENCZY, L., SZEGEDI, M., AND KEVEI, F. 1977. Interspecific protoplast fusion and complementation in Aspergilli. Experientia, 33, 184-186.

GAMBORG, O. L. 1977a. Protoplasts in genetic modification of plants. La Culture des Tissus et des Cellules des Vegetaux, ed. J. Gautheret, pp. 178-185. Masson et Cie, Paris.

GAMBORG, O. L. 1977b. Somatic cell hybridization by protoplast fusion and morphogenesis. Plant Tissue Culture and its Bio-technological Application, eds. W. Barz, E. Reinhard and M. H. Zenk, pp. 287-301. Springer-Verlag, Berlin.

GAMBORG, O. L., AND hOLL, F. B. 1977. Plant protoplast fusion and hybridization. Genetic Engineering for Nitrogen Fixation, ed. A. Hollaender et al., pp. 299-316. Plenum, New York. GAMBORG, O. L., OHYAMA, K., PELCheR, L. E., FOWKE, L. C., KARTHA, K., CONSTABEL, F., AND KAO, K. 1979. Genetic modification of plants. Plant Cell and Tissue Culture, Principle and Applications, eds. W. R. Sharp, P. O. Larsen, E. F. Paddock and V. Raghavan. Ohio State University Press, Ohio.

GERBAUD, C., FOURNIER, P., BLANC, H., AIGLE, M., HESLOT, M., AND GUERINEAU, M. 1979. High frequency of yeast transformation by plasmids carrying part or entire $2-\mu \mathrm{m}$ yeast plasmid. Gene, 5, 233-253.

GIAJA, J. 1922. Sur la levure depouillée de membrane. Compte rendus Soc. Biol., 86, 708-709. GILES, K. L. 1978. The uptake of organelles and microorganisms by plant protoplasts: old ideas but new horizons. Frontiers of Plant Tissue Culture, 1978, ed. T. A. Thorpe, pp. 67-74. International Association for Plant Tissue Culture, Calgary. 
GLEBA, Y. Y. 1979. Non-chromosomal inheritance in higher plants as studied by somatic cell hybridization. Plant Cell and Tissue Culture, Principle and Applications, eds. W. R. Sharp, P. O. Larsen, E. F. Paddock and V. Raghavan. Ohio State University Press, Ohio.

gleba, Y. Y., AND hoffmann, F. 1978. Hybrid cell lines Arabidopsis thaliana and Brassica campestris: no evidence for specific chromosome elimination. Molec. gen. Genet., 165, 257-264.

gleba, Y. Y., AND hoffman, F. 1979. Arabidobrassica: Plant genome engineering by protoplast fusion. Naturwissenschaften (in press).

GLIMEliUs, K., ERIKSsON, T., GRAFE, R., AND MULLER, A. 1978. Somatic hybridisation of nitrate reductase-deficient mutants of Nicotiana tabacum by protoplast fusion. Physiol. Plant., 44, 273-277.

GOSGH, G., AND REINERT, J. 1978. Cytological identification of colony formation of intergeneric somatic hybrid cells. Protoplasma, 96, 23-38.

Grimsley, N. H. 1978. Genetic analysis of the moss, Physcomitrella patens, using protoplast fusion. Ph.D. dissertation, University of Cambridge, England.

GRIMSLEY, N. H., ASHTON, N. W., AND COVE, D. J. 1977a. The production of somatic hybrids by protoplast fusion in the moss, Physcomitrella patens. Molec. gen. Genet., 154, 97-100.

GRIMSLEY, N. H., ASHTON, N. W., AND COVE, D. J. 1977b. Complementation analysis of auxotrophic mutants of the moss, Physcomitrella patens, using protoplast fusion. Molec. gen. Genet., 155, 103-107.

GUNGE, N., AND SAKAGUCHI, K. 1979. Fusion of mitochondria with protoplasts in Saccharomyces cerevisiae. Molec. gen. Genet., 170, 243-247.

hamilton, J. G., AND Galvet, J. 1964. Production of protoplasts in an osmotic mutant of Neurospora crassa without added enzyme. J. Bacteriol., 88, 1084-1086.

HAMLYN, P. F., AND BALL, G. 1979. Recombination studies with Cephalosporium acremonium. Genetics and Industrial Organisms. Proceedings of the Symposium on the Genetics of Industrial Microorganisms, eds. O. K. Sebek and A. I. Laskin, pp. 185-191. American Society for Microbiology, Washington, D.C.

HARMS, CH. T., AND POTRYKUS, I. 1978a. Enrichment for heterokaryocytes by the use of isoosmotic density gradients after plant protoplast fusion. Theor. appl. Genet., 53, 49-55.

HARMS, GH. T., AND POTRYKUs, I. 1978b. Fractionation of plant protoplast types by isoosmotic density gradient centrifugation. Theor. appl. Genet., 53, 57-63.

hinnen, A., Hicks, J. B., AND FINK, G. R. 1978. Transformation of yeast. Proc. natl. Acad. Sci., U.S.A., 75, 1929-1933.

HOFMEISTER, L. 1954. Mikrurgische Untersuchung über die geringe Fusionsneigung plasmolysierter, nackter Pllanzenprotoplasten. Protoplasma, 43, 278-326.

KAO, K. N. 1977. Chromosomal behaviour in somatic hybrids of Soybean-Nicotiana glauca. Molec. gen. Genet., 150, 225-230.

KAO, K. N., CONSTABel, F., MichayluK, M. R., AND GAMBorg, O. L. 1974. Plant protoplast fusion and growth of intergeneric hybrid cells. Planta (Berl.), 120, 215-227.

KAO, K. N., AND MICHAYLUK, M. R. 1974. A method for high frequency intergeneric fusion of plant protoplasts. Planta (Berl.), 115, 355-367.

KELlER, w. A., AND MELChers, G. 1973. The effect of high $p \mathrm{H}$ and calcium on tobacco leaf protoplast fusion. Z. Naturforsch., 28c, 737-741.

KEVEI, F., AND PEBERDY, J. F. 1977. Interspecific hybridisation between Aspergillus nidulans and Aspergillus rugulosus by fusion of somatic protoplasts. J. gen. Microbiol., 102, 255262.

KEVEI, F., AND PEBERDY, J. F. 1979. Induced segregation of interspecific hybrids of Aspergillus nidulans and Aspergillus rugulosus obtained by protoplast fusion. Molec. gen. Genet., 170, 213-218.

klergker, I. 1892. Eine Methode zur Isolierung lebender Protoplasten. Oefvers. Vet. Acad. Vorhandl., 9, 43.

KRUMBIEGEL, G., AND SGHIEDER, o. 1979. Selection of somatic hybrids after fusion of protoplasts from Datura innoxia Mill. and Atropa belladonna L. Planta, 145, 371-375.

KUNG, s. D., GRAY, J. G., Wildman, s. G., AND GARlson, P. s. 1975. Polypeptide composition of fraction I protein from parasexual hybrid plants in the genus Nicotiana. Science, 187, 353-355.

küstER, E. 1910. Eine Methode zur Gerwinnung abnorm grosser Protoplasten. Arch. Entw. Mech. Org., 30, 351-355.

LARKIN, P.J. 1977. Plant protoplast agglutination and membrane-bound $\beta$-lectins. $\mathcal{F}$. Cell Sci., 26, 31-46.

$43 / 3 \rightarrow B$ 
LARKIN, P. J. 1978a. Plant protoplast agglutination by artificial carbohydrate antigens. $\mathcal{F}$. Cell Sci., 30, 283-292.

LARKIN, P. J. 1978b. Plant protoplast agglutination by lectins. Plant Physiol., 61, 626629.

LOPEZ-BElmonte, F., GaRcia ACHA, I., AND villanueva, J. R. 1966 . Observations on the protoplasts of Fusarium culmorum and on their fusion. J. gen. Microbiol., 45, 127-134.

LURQUIN, P. F., AND KADO, C. I. 1977. Escherichia coli plasmid pBR313 insertion into plant protoplasts and into their nuclei. Molec. gen. Genet., 154, 113-121.

MALIGA, P. 1978. Resistance mutants and their use in genetic manipulation. Frontiers of Plant Tissue Culture, 1978, ed. T. A. Thorpe, pp. 381-392. Association of Plant Tissue Culture, Calgary.

MALIGA, P., KISS, z. R., H.-NAGY, A., AND LÁzÁR, G. 1978. Genetic instability in somatic hybrids of Nicotiana tabacum and Nicotiana knightiana. Molec. gen. Genet., 163, 145-151.

MALIGA, P., LÁzÁR, G., JOó, F, H.-NAGY, A., AND MENGZEL, L. 1977. Restoration of morphogenetic potential in Nicotiana by somatic hybridisation. Molec. gen. Genet., 157, 291296.

MELChers, G. 1977a. Microbial techniques in somatic hybridisation by fusion of protoplasts. International Cell Biology, 1976-7, eds. B. B. Brinkley and K. R. Porter, pp. 207-215. Rockefeller University Press.

MELCHERS, G. $1977 \mathrm{~b}$. Plant hybrids by fusion of protoplasts. Recombinant Molecules: Impact on Science and Society, eds. R. F. Beers, Jr., and E. G. Bassett, pp. 209-227. Raven Press, New York.

MELCHERS, G. 1977c. The combination of somatic and conventional genetics in plant breeding. Plant Research and Development, 5, 86-110.

MELCHERS, G., AND LABIB, G. 1974. Somatic hybridisation of plants by fusion of protoplasts. I. Selection of light resistant hybrids of " haploid " light sensitive varieties of tobacco. Molec. gen. Genet., 135, 277-294.

MELCHERS, G., AND SACRISTÁN, M. D. 1977. Somatic hybridisation of plants by fusion of protoplasts. II. The chromosome numbers of somatic hybrid plants of four different fusion experiments. La Culture des Tissus et des Cellules des Vegetaux, ed. J. Gautheret, pp. 169-177. Mason et Cie, Paris.

MELCHERS, G., SACRISTÁN, M. D., AND HOLDER, A. A. 1978. Somatic hybrid of potato and tomato regenerated from fused protoplasts. Carisberg Res. Commun., 43, 203-218.

MENCZEL, L., LÁzÁR, G., AND MALIGA, P. 1978. Isolation of somatic hybrids by cloning Nicotiana heterokaryons in nurse cultures. Planta, 143, 29-32.

Michel, w. 1937. Über die experimentelle Fusion pflanzlicher Protoplasten. Arch. exp. Zellforsch., 20, 230-252.

MISHRA, N. C., SZABO, G., AND TATUM, E. L. 1973. Nucleic acid induced genetic changes in Neurospora. The Role of RNA in Reproduction and Development, eds. M. C. Niu and S. J. Segal, pp. 261-273. North-Holland Publ. Co., Amsterdam.

MÜLLER, A. J., AND GRAFE, R. 1978. Isolation and characterisation of cell lines of Nicotiana tabacum lacking nitrate reductase. Molec. gen. Genet., 161, 67-76.

NAGATA, T., AND TAKEBE, I. 1970. Cell wall regeneration and cell division in isolated mesophyll protoplasts. Planta (Berl.), 92, 301-308.

NAGATA, T., AND TAKEBE, I. 1971. Plating of isolated tobacco mesophyll protoplasts on agar medium. Planta, 99, 12-20.

NEČAs, O. 1956. Regeneration of yeast cells from naked protoplasts. Nature (Lond.), 177, 898-899.

NITSCH, J. P., AND OHYAMA, K. 1971. Obtention de plantes à partir de protoplastes haploides cultivés in vitro. C. R. Acad. Sci. Paris, Series D, 273, 801-804.

OHYAMA, K., PElGher, L. E., AND HORN, D. 1977. A rapid, simple method for nuclei isolation from plant protoplasts. Plant Physiol., 60, 179-181.

PEBERDY, J. F., EYSSEN, H., AND ANNÉ, J. 1977. Interspecific hybridisation between Penicillium chrysogenum and Pencillium cyaneo-fulvum following protoplast fusion. Molec. gen. Genet., 157, 281-284.

POJNAR, E., WILlison, J. H. M., AND COCKING, E. C. 1967. Cell-wall regeneration by isolated tomato-fruit protoplasts. Protoplasma, 64, 460 480.

POTRYkUs, I., 1973. Transplantation of chloroplasts into protoplasts of Petunia. Z. Pflanzenphysiol., 70, 364-366.

potrykus, 1. 1975. Uptake of cell organelles into isolated protoplasts. Modification of the Information Content of Plant Cells, eds. R. Markham, D. R. Davies, D. A. Hopwood and R. W. Horne, pp. 169-179. North-Holland Publ. Co., Amsterdam and Oxford. 
POTRYKUS, I., HARMS, C. T., AND LöRz, H. 1976. Problems in culturing cereal protoplasts. Cell Genetics in Higher Plants, eds. D. Dudits, G. L. Farkas and P. Maliga, pp. 129-140. Akadémiai Kiadó, Budapest.

POTRYKUS, I., HARMS, C. T., LöRz, H., AND ThOMAS, E. 1977b. Callus formation from stem protoplasts of corn (Zea mays L.). Molec. gen. Genet., 156, 347-350.

POTRYKUS, I., AND hOFFMAN, F. 1973. Transplantation of nuclei into protoplasts of higher plants. Z. Pflanzenphysiol., 69, 287-289.

POTRYKUS, I., LöRZ, H., AND HARMS, C. T. 1977a. On some selected problems and results concerning culture and genetic modification of higher plant protoplasts. Plant Tissue Culture and its Bio-technological Application, eds. W. Barz, E. Reinhard and M. H. Zenk, pp. 323-333. Springer, Berlin, Heidelberg and New York.

POWER, J. B., BERRY, S. F., FREARSON, E. M., AND COCKING, E. C. 1977. Selection procedures for the production of interspecies somatic hybrids of Petunia hybrida and Petunia parodii. I. Nutrient media and drug sensitivity complementation selection. Plant Science Letters, $10,1-6$.

POWER, J. B., CUMMins, S. E., AND COCKING, E. C. 1970. Fusion of isolated plant protoplasts. Nature (Lond.), 225, 1016-1018.

PoWER, J. B., FREARSON, E. M., HAYWARD, C., GEORGE, D., EVANS, P. K., BerRy, S. F., AND COcking, E. c. 1976. Somatic hybridisation of Petunia hybrida and Petunia parodii. Nature (Lond.), 263, 500-502.

RUDDle, F. H., AND CREAGAN, R. P. 1975. Parasexual approaches to the genetics of man. Ann. Rev. Genetics, 9, 407-488.

SACRISTÁN, M. D., AND MELCHERS, G. 1969. The caryological analysis of plants regenerated from tumorous and other callus cultures of tobacco. Molec. gen. Genet., 105, 317-333.

SCHENK, R. U., AND HILDEBRANDT, A. C. 1970. Reproduction, manipulation and fusion of plant cell protoplasts as steps toward somatic hybridisation. Les Cultures de Tissus de Plantes, eds. M. L. Hirth and M. G. Morel, pp. 319-331. Éditions du Centre Nationale de Recherche Scientifique, 1971.

SCHIEDER, O. 1974. Selektion einer somatischen Hybride nach Fusion von Protoplasten auxotropher Mutanten von Sphaerocarpus donnellii AUST. Z. Pflanzenphysiol., 74, 357-365.

SCHIEDER, O. 1977a. Hybridisation experiments with protoplasts from chlorophyll-deficient mutants of some Solanaceous species. Planta, 137, 253-257.

SCHIEDER, O. 1977b. Attempts in regeneration of mesophyll protoplasts of haploid and diploid wild-type lines, and those of chlorophyll-deficient Solanaceae. Z. Pfanzenphysiol., 84, S. 275-281.

SCHIEDER, O. 1978a. Somatic hybrids of Datura innoxia Mill. and Datura discolor Bernh. and of Datura innoxia Mill. and Datura stramonium L. var. tatula L. Molec. gen. Genet., 167, 113-119.

SCHIEDER, O. 1978b. Genetic evidence for the hybrid nature of somatic hybrids from Datura innoxia Mill. Planta, 141, 333-334.

SIPICZKI, M., AND FERENCZy, L. 1977a. Protoplast fusion of Schizosaccharomyces pombe auxotrophic mutants of identical mating-type. Molec. gen. Genet., 151, 77-81.

SIPICZKI, M., AND FERENCZY, L. 1977b. Fusion of Rhodosporidium (Rhodotorula) protoplasts. FEMS Microbiology Letters, 2, 203-205.

SMrTH, н. H. 1978. New avenues of research in plant genetics and breeding. Annales de Tabac, (in press).

SMTTH, H. H., KAO, K. N., AND COMBATTI, N. G. 1976. Interspecific hybridization by protoplast fusion in Nicotiana. 7. Hered., 67, 123-128.

STAHL, U. 1978. Zygote formation and recombination between like mating-types in the yeast Saccharomyces lipolytica by protoplast fusion. Molec. gen. Genet., 160, 111-113.

SUZUKI, M., TAKEBE, I., KAJITA, s., HONDA, Y., AND MATSUI, c. 1977. Endocytosis of polystyrene spheres by tobacco leaf protoplasts. Exp. Cell. Res., 105, 127-135.

svoboda, A. 1977. Mating reactions in yeast protoplasts. Arch. Microbiol., 110, 313-318.

TAKEBE, I., LABIB, G., AND MELCHERs, G. 1971. Regeneration of whole plants from isolated mesophyll protoplasts of tobacco. Naturwissenschaften, 58, 318-320.

uCHMrYA, H. 1979. Chloroplast adherence to plant protoplasts. Specific interactions of $p \mathrm{H}$, calcium and PEG. Naturwissenschaften, 66, 314-315.

VASIL, I. K., AHUJA, M. R., AND VASIL, v. 1978. Plant tissue cultures in genetics and plant breeding or some alternatives to sex in plants through tissue culture. Adv. Genet., 20 (in press).

VASIL, I. K., AND GILES, K. L. 1975. Induced transfer of higher plant chloroplasts into fungal protoplasts. Science, 190, 680. 
villanueva, J. R. 1966. Protoplasts of fungi. The Fungi, vol. 2, The Fungal Organism, eds. G. C. Ainsworth and A. S. Sussman, pp. 3-62. Academic Press, New York.

WALLIN, A., GLIMELIUS, K., AND ERIKSSON, T. 1974. The induction of aggregation and fusion of Daucus carota protoplasts by polyethyleneglycol. Z. Pfanzenphysiol., 74, 64-80.

WAllin, A., GLimelius, K., AND ERIKsson, T. 1978. Enucleation of plant protoplasts by cytochalasin. B. Z. Pfanzenphysiol., 87, 333-340.

WALLIN, A., GLIMELIUS, K., AND ERIKSSON, T. 1979. Formation of hybrid cells by transfer of nuclei via fusion of mini-protoplasts from cell lines of nitrate reductase-deficient tobacco. Z. Pflanzenphysiol., 91, 89-94.

WEIBULL, c. 1953. The isolation of protoplasts from Bacillus megaterium by controlled treatment with lysozyme. 7. Bacteriol., 66, 688-695.

WILKIE, D., AND THOMAS, D. Y. 1973. Mitochondrial genetic analysis by zygote cell lineage in Saccharomyces cerevisiae. Genetics, 73, 367-377.

ZENKTEL.ER, M., AND MELCHERS, G. 1978. In vitro hybridization by sexual means and by fusion of somatic protoplasts. Experiments with Nicotiana tabacum + Petunia hybrida, $\mathcal{N}$. tabacum $\times$ Hyoscyasmus niger, $H$. niger $\times P$. hybrida, Melandryum album $\times P$. hybrida. Theor. appl. Genet., 52, 81-90. 